Nordisk Tidsskrift for Kriminalvidenskab 2004

\title{
UDVIKLINGEN AF DE STRAFFERETLIGE SANKTIONER I ISLAND
}

AF PROFESSOR RAGNHEIDUR BRAGADÓTTIR

The discussion of criminal policy matters has increased in Iceland in recent years. There has been a tendency towards more severe punishment. Yet at the same time, new sanctions have been introduced to the criminal justice system, which in some cases replace imprisonment. New sanctions include alcohol and drug treatment during sentences of imprisonment in closed institutions, sentences of imprisonment and probation in open institutions, and community service. This article describes recent developments in the Icelandic criminal justice system as they relate to both new sanctions and traditional ones - such as suspended sentences and parole supervision.

\section{Indledning}

Det islandske samfund har i de seneste år undergået en stor forvandling og det er blevet en del mere indviklet og uoverskueligt. Man har i stadig højere grad kontakt til andre lande og af den grund har borgerne en større indsigt $i$ andre nationers levevis og levevilkår. Dette har medført øget oplysning og mangfoldighed. Men i kølvandet af internationaliseringen og globeliseringen følger også en stigende materialisme, en større hastighed og brutalitet på alle felter. Man mærker en stigende interesse for massemediernes daglige dækning af kriminalitet, men der er dog ikke nødvendigvis et sammenfald mellem denne stigende interesse og en stigning i kriminaliteten, som den almene borger dog ser ud til at mene.

\section{Kriminalpolitik i det forgangne årti}

Den debat, som i 70'erne blev ført i de nordiske lande omkring sanktionssystemet og nye sanktionsformer som alternativ til ubetinget frihedsstraf, blev kun i begrænset grad ført i Island. Det kan til dels forklares ved, at i Island anvendtes fængselsstraf i mindre grad end i nabolandene, og at straffe har været kortere. Derfor er det samme behov for at begrænse anvendelsen af ubetinget frihedsstraf ikke opstået. I 1990 til 1995 er der dog alligevel blevet indført tre nye elementer inden for sanktionssystemet, der har haft stor betydning i retning af at begrænse antallet af fanger og at forkorte afsoningstiden i fængsel indtil året 2000, selv om andre faktorer har medvirket hertil, såsom færre domme. De tre elementer er: alkohol- og narkotikabehandling under afsoningen; afsoning af frihedsstraf og

* Title in English: Trends in Penal Sanctions in Iceland. Original in Danish. 
vilkårstilsyn hos foreningen "Vernd"1; samfundstjeneste. Alle disse elementer bygger på loven om fængsler og fængselsophold fra 1988. Initiativet til disse sanktioner, som de har udviklet sig, kom fra forvaltningen, men ikke fra den lovgivende magt. Der er ikke blevet ført megen debat i samfundet om disse sanktioner, eftersom de heller ikke er i overensstemmelse med de mest højrøstede holdninger omkring behandlingen af de kriminelle.

I de seneste år har man kunnet mærke en øget debat om forskellige kriminalpolitiske anliggender. Man har lavet udførlige rapporter og unders $ø$ gelser om adskillige temaer, fx vold i hjemmet, seksualforbrydelser mod børn, offerets retsstilling, unge kriminelle, prostitution og straf for voldsforbrydelser. En ting er dog forblevet uændret til trods for store samfundsændringer i de seneste år. Og det er at debatten om kriminalpolitik, ikke mindst om selve straffen, oftest knytter sig til bestemte sager. Det som ofte tilskynder at bestemte sider af sanktionssystemet sættes under en lup er at der sker alvorlige forbrydelser og at man $\emptyset n$ nker at skride ind. Det er så her at kravet om strengere straffe kommer frem. Straffemaksima for seksualforbrydelser mod børn er blevet forhøjet og domme for seksualforbrydelser bliver alment strengere. Straffemaksima for narkotikaforbrydelser er også blevet forhøjet. Blandt andet derfor stiger nu antallet af fanger, som har været stabilt i de sidste år, omkring 40 fanger for hver 100.000 indbyggere pr. dag. Der blev ikke foretaget nogen kriminalvidenskabelig forsk-ning i hvorvidt og i så fald hvilket resultat denne forhøjelse skulle give, inden man gik i gang med denne lovændring. Ved at forhøje straffemaksima i loven vil politikerne dæmpe de almene borgeres utilfredshed, men de mener at tilstandene er betydelig værre end de faktisk er. Derved tror de også at de har løst problemet. På den anden side tænkes der mindre på hvad der sker med de dømte når de kommer ud efter et langt fængselsophold eller i hvilken tilstand de så befinder sig.

\section{Sanktionssystemets grunde}

Det fremgår ikke af fængselsloven, hverken i selve loven eller i bemærkningerne med lovforslaget, hvilket formål sanktionssystemt har. Dette gælder for den nugældende lov om fængsler og fængselsophold nr. 48/1988 (forkortet til fl.), den lov der gjaldt før den nr. 38/1973 om fængsler og arbejdsanstalter samt et forslag til en ny lov om fuldbyrdelse af straf, der nu forelægges Altinget. I bemærkningerne med forlaget til den nugældende lov fra 1988 stod der at lovforslaget tog sigte på de gældende forhold i fængselsanliggender i Island og at man ikke regnede med grundlæggende ændringer i fuldbyrdelsen af ubetingede fængselsdomme. ${ }^{2}$ I det nye lovforslag om fuldbyrdelse af straf regner

\footnotetext{
1 "Vernd": ("Beskyttelse"), en forening der har hjulpet fanger i 40 år.

${ }^{2}$ Altingstidende, 1987-88, A-del s. 2087.
} 
man med at forskellige bestemmelser om fangers rettigheder og pligter, der nu står i bekendtgørelser, vil indgå i loven med det formål at gøre de gældende regler klarere og styrke visse bestemmelsers lovgrundlag. ${ }^{3}$ På den anden side fremgår det ingen steder hvad man ønsker at opnå med fængselsstraffen. En kommentar til dette finder man derimod i bemærkningerne til straffeloven $\mathrm{nr}$. 19/1940. Der siger man at formålet med straf først og fremmest er beskyttelse af den almene retssikkerhed og opretholdelsen af den lovbundne samfundsorden. Straffen tilfredsstiller endvidere den almene borgers retfærdighedssans, der ikke vil acceptere at folk ustraffet kan krænke andre menneskers rettigheder. Til slut er det formålet med straffen at have en almen og specialpræventiv virkning, men at man ikke sigter mod at den kan medvirke til at forbedre den afstraffedes karakter. ${ }^{4}$ Dette er således det proklamerede formål med straf i Island og har været det i 65 år.

\section{Samfundssanktioner}

I den islandske lovgivning findes der bestemmelser om adskillige samfundsmæssige sanktioner. Det er både sanktioner der har været gældende i årtier fx betinget tiltalefrafald og betingede domme, såvel som nyere tilbud som samfundstjeneste. Jeg vil drøfte betinget tiltalefrafald i et senere kapitel om unge kriminelle, eftersom det næsten uden undtagelse anvendes på dem.

\section{Betingede domme}

En hjemmel til at betinge domme bygger på straffelovens § 57. Det er tilladt at udsætte med vilkår straffastsættelse eller straffuldbyrdelse. Prøvetiden sættes normalt til 2-3 år. Det er et obligatorisk vilkår at den dømte ikke bliver fundet skyldig i en ny overtrædelse af loven under prøvetiden. Der fastsættes sjældent andre vilkår i betingede domme.

Følgende tabel viser frihedsstraffene, som Fængselsdirektoratet fik tilsendt til fuldbyrdelse i 1998-2002, fordelt mellem betingede eller ubetingede straffe. ${ }^{5}$

\begin{tabular}{|c|c|c|c|c|c|}
\hline & 1998 & 1999 & 2000 & $\underline{2001}$ & $\underline{2002}$ \\
\hline Ubetinget frihedsstraf + evt. andet & 305 & 258 & 313 & 302 & 312 \\
\hline Betinget frihedsstraf + evt. bøde & 420 & 374 & 403 & 440 & 406 \\
\hline
\end{tabular}

\footnotetext{
${ }^{3}$ http://www.althingi.is/altext/130/s/0673.html

${ }^{4}$ Altingstidende, 1939, A-del, s. 352-353.

${ }^{5}$ Fængselsdirektoratets årsrapport for året 2002, s. 30.
} 
Det er udbredt at unge forbrydere får betingede domme. Der er eksempler på at dette er sket i alvorlige sager, fx H. 1987:700, hvor en 15 årig dreng, der slog en anden dreng ihjel, blev idømt en 4 års betinget fængselsstraf og H. 2000:1722, hvor en 17 årig dreng blev idømt 15 måneders betinget fængselsstraf for voldtægt.

\section{Samfundstieneste}

Samfundstjeneste blev indført som forsøgsordning i $1995 \mathrm{og}$ havde gyldighed i to og et halvt år, jfr. lov nr. 55/1994. Ifølge loven var der hjemmel til at fuldbyrde op til 3 måneders ubetinget frihedsstraf ved udførelse af samfundstjeneste, mindst 40 timer og højst 120 timer, i henhold til bestemte vilkår. Mens loven havde gyldighed, blev omkring $40 \%$ af de ubetingede frihedsstraffe på tre måneder eller derunder fuldbyrdet med samfundstjeneste. De fleste af de dømte som afsonede ved samfundstjeneste blev dømt for promillekørsel. Forsøget med samfundstjeneste var utvivlsomt vellykket, og ordningen blev lovfæstet permanent i lov om fængsler og fængselsophold nr. 48/1988, jfr. lov nr. 123/1997. Begrundelsen for det var, at denne ordning er en måde at fuldbyrde en ubetinget frihedsstraf på, hvorfor den hører hjemme i samme lov som andre bestemmelser om fuldbyrdelse af ubetinget frihedsstraf. I $1999 \mathrm{blev}$ der endvidere, jfr. lov nr. 22/1999, tilføjet bestemmelser om samfundstjeneste som fuldbyrdelse af forvandlingsstraf. Man tilføjede disse bestemmelser som en reaktion på det herskende misforhold der var mellem dem, der på den ene side afsonede en fængselsstraf og på den anden side dem der afsonede en bødeforvandlingsstraf, eftersom de sidstnævnte ikke har ret til prøveløsladelse.

Det er forvaltningen, der afgør, om samfundstjeneste kan anvendes. Sådan har det været fra begyndelsen. Fængselsdirektoratet træffer afgørelsen om samfundstjeneste på samme måde, som det gør om orlov fra afsoning, prøveløsladelse og afsoningssted. Direktoratet afgør desuden, hvilket arbejde den dømte skal udføre, og over hvor lang tid, det skal udføres. Den tid kan dog aldrig blive kortere end to måneder, jfr. fl. § 24, stk. 1. I lov nr. 123/1997 var det en nyhed, at Fængselsdirektoratets afgørelser om samfundstjeneste kan appelleres til justitsministeren, og det giver den dømte større retssikkerhed. Justitsministeren tager derfor den endelige beslutning om ansøgninger om samfundstjeneste, efter forslag fra benådningsudvalget.

I perioden 1998 til 2002 var antallet af dem der fik mulighed for samfundstjeneste i stedet for ubetinget fængselsstraf og bødeforvandlingsstraf som det fremgår her. ${ }^{6}$

\begin{tabular}{|c|c|c|c|c|}
\hline & 1998 & 1999 & 2000 & 2001 \\
\hline Samfundstj. i st. f. ubet. fængsel & 84 & 60 & 80 & 82 \\
\hline Samfundstj. i st. f. bødeforvandl. & 0 & 0 & 52 & 60 \\
\hline
\end{tabular}

\footnotetext{
${ }^{6}$ Fængselsdirektoratets årsrapport for året 2002, s. 19.
} 
A. Samfundstjeneste som alternativ til fuldbyrdelse af ubetinget faengselsstraf Ifølge den nugældende lov er der hjemmel til at fuldbyrde op til 6 måneders ubetinget fængsel med ulønnet samfundstjeneste, mindst 40 timer og højst 240 timer, jfr. fl. $\S 22$, jfr. $\S 4$, lov nr. 123/1997. 40 timers samfundstjeneste er lig med en måneds fængselsstraf. Der er ikke hjemmel til at fuldbyrde straf ved samfundstjeneste, hvis det strider mod almenhedens interesse, jfr. § 22, stk. 1, eftersom samfundstjeneste ikke må svække straffens almenpræventive virkning. Den kan især komme på tale, hvor specialpræventive formål har betydning for strafudmålingen, f.eks. ved berigelsesforbrydelse og dokumentfalsk.

Forudsætninger for at fuldbyrde en dom ved samfundstjeneste er, at den dømte ikke må have uafsluttede sager vedrørende strafbare forhold. Han skal også vurderes egnet til samfundstjeneste. Ved vurdering heraf tages der hensyn til personlige forhold og tidligere kriminalitet. Sandsynligheden for, at samfundstjeneste kan føre til, at den dømte vil forlade den kriminelle bane, skal også vurderes. Hvis en person ofte har afsonet frihedsstraf, er det usandsynligt at han kan yde samfundstjeneste. Forbrydelsens karakter har også betydning, idet samfundstjeneste forholdsvis sjældent bevilges til personer, der er dømt for narkotikakriminalitet, hærværk eller vold. De fleste som afsoner ved samfundstjeneste bliver dømt for overtrædelser af færdselsloven og brugstyveri (64\% i 2002) og den næststørste gruppe bliver dømt for berigelsesforbrydelser og dokumentfalsk ( $12 \%$ i 2002). ${ }^{7}$

Der er to vilkår, som altid skal gives for samfundstjeneste, jfr. fl. § 25 . For det første må den dømte ikke gøre sig skyldig i strafbar handling i løbet af den tid, samfundstjenesten udføres. For det andet skal han være under tilsyn og kontrol af en person, en forening eller institution i den tid, han fuldbyrder sin dom ved samfundstjeneste. Desuden er der hjemmel til at give de vilkår, der kan gives i forbindelse med en betinget dom, jfr. straffelovens $\S 57$, stk. 3, 2.-6. Disse vilkår vedrører bl. a. forskrifter om opholdssted, uddannelse, arbejde, samkvem med andre, fritidsbeskæftigelse og afhold fra brug af alkohol og narkotika.

Hvis den dømte overtræder vilkårene for samfundstjenesten eller ikke udfører den på tilfredsstillende måde, afgør Fængselsdirektoratet, om vilkårene skal ændres, om den tid, hvori samfundstjenesten udføres, skal forlænges, eller om dommen skal afsones i fængsel, jfr. fl. § 26. Hvis den dømte overtræder vilkårene for samfundstjenesten ved at begå en ny forbrydelse under prøvetiden, d.v.s. er sigtet for at have begået strafbar handling efter at beslutningen om at fuldbyrde dommen ved samfundstjeneste er truffet, kan Fængselsdirektoratet tilbagekalde afgørelsen og beslutte, at den dømte skal afsone frihedsstraffen. Hvis en vilkårsovertrædelse eller en ny forbrydelse ikke er alvorlig eller gentager sig, får den dømte en advarsel, i stedet for at afsone fængselsstraffen.

\footnotetext{
${ }^{7}$ Fængselsdirektoratets årsrapport for året 2002, s. 34.
} 
I perioden 1995-2002 overtrådte 13\% af de dømte, der afsonede en ubetinget fængselsdom ved samfundstjeneste, de stillede vilkår for samfundstjenesten. ${ }^{8}$

\section{B. Fuldbyrdelse af forvandlingsstraf med samfundstjeneste}

Hvis politimesteren har besluttet, at en person skal afsone bødeforvandlingsstraf, er der hjemmel for, hvis ikke det går imod almenhedens interesse, at fuldbyrde forvandlingsstraffen med ulønnet samfundstjeneste, jfr. fl. § 26, jfr. lov nr. 22/1999. Mindstetiden er 20 timer og længstetiden 480 timer. Den maksimale forvandlingsstraf på ét år skal fuldbyrdes med 480 timers samfundstjeneste. Hvis en person er blevet idømt både ubetinget fængsel og en bøde, er det ikke muligt at fuldbyrde forvandlingsstraffen med samfundstjeneste i de tilfælde, hvor den sammenlagte fængselsstraf og forvandlingsstraf overstiger ét år.

I perioden 1995-2002 overtrådte $20 \%$ af de dømte som afsonede bødeforvandlingsstraf ved samfundstjeneste de stillede vilkår for samfundstjenesten. ${ }^{9}$

\section{Fængsel}

\section{Afsoningsfangers ophold udenfor foengslet}

Fanger kan få tilladelse til ophold uden for fængslet, uden ledsagelse, helt op til 14 timer, for at bes $\varnothing$ ge deres bopæl eller at besøge familie eller venner, hvis dette anses for at være en hensigtsmæssig del i fuldbyrdelsen af en straf eller som en del i forberedelserne for at fangen afslutter sin afsoning og kommer igen ud i det frie samfund, jf. 2. afsnit i bekendtgørelse nr. 719/1995 om afsoningsfangers ophold uden for fængslet. For at kunne få denne en-dags udgang skal fangen have afsonet 1/3 del af straffetiden og mindst ét år. En-dags udgang er således kun for fanger der afsoner en fængselsstraf på tre år eller mere og betingelserne er god opførsel under fængselsopholdet. Det første år får fanger en-dags udgang med to måneders mellemrum, men siden én gang om måneden. Året 2002 fik i alt 37 fanger sammenlagt 130 endags udgang. . $^{\circ}$

Desuden er der hjemmel for at give tilladelse til fangers ophold uden for fængslet for at de kan passe et arbejde, en uddannelse eller en praktik. Betingelserne er at fangen har afsonet mindst ét år og at man regner med at der går mindre end 3 måneder indtil hans afsoning er forbi, hvis det drejer sig om arbejde, men mindre end 6 måneder hvis det drejer sig om uddannelse eller praktik.

\footnotetext{
${ }^{8}$ Fængselsdirektoratets årsrapport for året 2002, s. 19.

${ }^{9}$ Fængselsdirektoratets årsrapport for året 2002, s. 20.

${ }^{10}$ Fængselsdirektoratets årsrapport for året 2002, s. 14.
} 


\section{Prøveløsladelse}

Fængselsdirektoratet kan indrømme en prøveløsladelse når en fange har afsonet $2 / 3$ dele eller $1 / 2$ delen af straffetiden, jf. straffelovens $\S 40$. Det er altid et vilkår for prøveløsladelse at fangen ikke bliver fundet skyldig i en ny lovovertrædelse under prøvetiden og det er tilladt at fastlægge vilkår om tilsyn. Omkring $60 \%$ af alle fanger bliver prøveløsladt, men omkring $40 \%$ afsoner deres fulde straf. Hovedårsagerne til at der ikke indrømmes prøveløsladelse er når fangen har en uafsluttet sag i retssystemet eller at han anses for at være en vaneforbryder. I de seneste år har omkring $18 \%$ af dem, der har fået prøveløsladelse, begået en lovovertrædelse under prøvetiden. ${ }^{11}$ Sidste oktober nedsatte justitsministeren et udvalg, der skulle unders $\varnothing$ ge om der var grund til at ændre udførelsen af prøveløsladelser således at det blev en dommer i stedet for Fængselsdirektoratet, der afgjorde en prøveløsladelse. Udvalget foreslog uændret ordning.

\section{Alkohol- og narkotikabehandling under afsoning af frihedsstraf}

Statens fængselsdirektorat indgik i 1990 en aftale med SÁÁ ${ }^{12}$ om at give en del af fangerne mulighed for at afsone de sidste uger af deres frihedsstraf $\mathrm{i}$ alkohol- og narkotikabehandling på SÁÁ's behandlingsinstitutioner med hjemmel i fl. § 11 . De, der bevilges afsoning i behandling, afslutter som regel en længere straf, og behandlingen sker ofte i forbindelse med en prøveløsladelse med vilkår og med henblik på bedre at forberede fangen på livet efter afsoningen. Fængselsdirektoratet bevilger dette i samråd med SÁÁ's overlæge. Fængselsdirektoratets beslutning kan appelleres til justitsministeren med en forvaltningskære. I de tilfælde, hvor behandlingen bevilges, underskrives der en aftale mellem Fængselsdirektoratet og fangen. Der sættes bestemte vilkår for behandlingen, og direktoratet afgør i samråd med SÁÁ's overlæge, hvornår behandlingen begynder. Fangen vil så afsone frihedsstraffens sidste 6 uger i behandling. Hvis fangen forlader behandlingsinstitutionen uden Fængselsdirektoratets viden eller samtykke, anses det som undvigelse, der kan straffes med disciplinærstraf. Hvis han overtræder vilkårene for opholdet eller afbryder behandlingen, skal han afslutte afsoningen i fængsel.

\footnotetext{
${ }^{11}$ Rapport om prøveløsladelse, s. 19.

${ }^{12}$ SÁÁ / "Samtök áhugafólks um áfengis- og vímuefnavandann": En interesseorganisation om alkohol- og narkotikaproblemet.
} 
Af tabellen nedenfor fremkommer der antallet af afsonere i behandling hos SÁÁ, 1995-2002, fordelt efter om behandlingen er afsluttet eller ej. ${ }^{13}$

$\begin{array}{lllllllll} & 1995 & 1996 & 1997 & 1998 & 1999 & 2000 & 2001 & 2002 \\ \text { Afsl. behandling } & 20 & 32 & 20 & 13 & 17 & 12 & 18 & 15 \\ \text { Ikke afsl. behandl. } & 5 & 9 & 10 & 5 & 8 & 3 & 10 & 6 \\ \text { Afsoner i bh. i alt } & 25 & 41 & 30 & 18 & 25 & 15 & 28 & 21\end{array}$

Det fremgår af tabellen, at i gennemsnit har 3 ud af 4 afsluttet behandlingen. Året 1999 indførte man den nyhed, at unge dømte blev tilbudt behandling i begyndelsen af afsoning.

\section{Afsoning af frihedsstraf og vilkårstilsyn hos foreningen "Vernd"}

Afsoning på organisationen "Vernds" hjem begyndte i 1995 og byggede på samme hjemmel i loven som alkohol- og narkotikabehandling under afsoning af frihedsstraf, d.v.s. fl. §11, stk. 1. Senere fandt man anledning til at lovfæste en nærmere hjemmel i denne praksis og der blev gjort med et nyt stykke, stk. 2, som blev tilføjet fl. §11 med lov nr. 22/1999. Der fremgår det at Fængselsdirektoratet kan bevillige at en fange afsoner sin straf udenfor fængslet, hvis denne arbejder eller er under uddannelse, som direktoratet har godkendt, bor på en speciel institution eller på et hjem, hvor han er under tilsyn og arbejdet eller uddannelsen er et led i fangens tilpasning til samfundet.

To grupper af dømte kan få ophold hos "Vernd". Det er for det første personer, der har fået længere domme, og som har afsonet en del af dommen og udvist god opførsel under afsoningen. For det andet drejer det sig om personer, der er blevet idømt kortere domme, har fast arbejde eller er under uddannelse, og som kun har afsonet kort tid. Bestemte vilkår sættes for afsoning hos "Vernd". Afsoningen må ikke gå imod almenhedens interesser, den dømte må have et godkendt arbejde eller være under uddannelse under afsoningen hos "Vernd", overholde aftaler om mødetider på institutionen, være totalt afholdende mht. alkohol og narkotika, ikke have uafgjorte sager kørende i retssystemet, og afsoningens sluttidspunkt skal være nogenlunde klart, d.v.s. man ved om/hvornår den dømte skal prøveløslades.

Både Fængselsdirektoratet og "Vernd" skal godkende opholdet. Hvis Fængselsdirektoratet afviser en ansøgning, kan afgørelsen appelleres til Justitsministeriet. Hvis "Vernds" husnævn til gengæld vurderer, at ansøgeren ikke er egnet til afsoning hos "Vernd", er den afgørelse endelig. Udgifter i forbindelse med ophold hos "Vernd" afholdes af den dømte. Tilsyn med de dømte varetages først og fremmest af "Vernds" personale, men også af Fængselsdirektoratet. Hvis den dømte overtræder Fængselsdirektoratets vilkår, "Vernds" husreglement eller

\footnotetext{
${ }^{13}$ Fængselsdirektoratets årsrapport for 2002, s. 14.
} 
begår en ny forbrydelse, kan Fængselsdirektoratet bringe ham til afsoning i fængsel og give ham disciplinærstraf.

De, der bevilges ophold hos "Vernd", har alle afsonet en del af frihedsstraffen i et fængsel. Fængselsdirektoratets regler om afsoning på hjemmet siger, at en fange skal have afsonet mindst $1 / 3$ del af straffen i fængsel, inden han får mulighed for afsoning hos "Vernd". Maksimal afsoningstid hos "Vernd" er 6 måneder.

I tabellen nedenfor ses antallet af bevilgede afsoninger hos "Vernd", 1995-2002, fordelt efter om vilkårene er overholdt eller overtrådt. ${ }^{14}$

Overholdt vilkår for ophold

Vendt tilbage til fængsel

Antal bevilgede afson. $\mathrm{i}$ alt

$\begin{array}{lllll}1998 & 1999 & 2000 & 2001 & 2002 \\ 34 & 33 & 33 & 37 & 36 \\ 8 & 14 & 4 & 6 & 7 \\ 42 & 47 & 37 & 43 & 43\end{array}$

\section{Unge kriminelle}

\section{Tiltalefrafald}

I henhold til straffelovens $\S 56$ er der hjemmel til at udsætte med betingelser påtale $\mathrm{i}$ forbindelse med lovovertrædelser begåede af unge $\mathrm{i}$ alderen 15-21 år. Det er en forudsætning at de unge har tilstået overtrædelsen. De er under tilsyn under prøvetiden, der normalt er sat til to år. De fleste der er bevilget betinget tiltalefrafald er i alderen 15-17 år. I 2002 havde omkring 66\% af dem gjort sig skyldige i berigelsesforbrydelser og omkring $23 \%$ i brugstyveri. ${ }^{15}$ De unge bevilges kun én gang betinget tiltalefrafald. Bliver de igen skyldige rejses der påtale. Man formoder at omkring $75 \%$ af de unge holder betinget tilfalefrafald. ${ }^{16}$

\section{Afsoning på behandlingshjem}

I 1998 indgik Fængselsdirektoratet og Direktoratet for børneværn en aftale om at fanger under 18 år, i stedet for afsoning i fænglser, bliver anbragt på behandlingshjem, der drives i overensstemmelse med bestemmelser i loven om værn af børn og unge. Der indgås en skriftlig aftale med den dømte og dennes værge om en seks måneders afsoning under behandling, uanset straffedommens længde. Hvis fangen overtræder de givne vilkår, fx forsøger at flygte, skal han afsone resten af dommen i fængsel. I årene 2001 og 2002 var der ingen fanger i alderen 16-17 år i islandske fængsler.

\footnotetext{
${ }^{14}$ Fængselsdirektoratets årsrapport for 2002, s. 16.

${ }^{15}$ Fængselsdirektoratets årsrapport for 2002, s. 46.

${ }^{16}$ Rapport om unge kriminelle, s. 31 .
} 


\section{3. "Restorative Justice"}

I de seneste tre år har man arbejdet på et fors $\emptyset$ gsprojekt i "restorative justice" ånd $\mathrm{i}$ et af Reykjavíks yngre boligkvarerer. Der har utilregnelige unge (d.v.s. børn under 15 år), de fleste i alderen 12-15 år, der har gjort sig skyldige i tingsødelæggelse eller tyveri, fået mulighed for at kompensere for deres opførsel på en opbyggelig måde ved samfundets assistance. Foruden at børnene får en mulighed for at kompensere for deres overtrædelse, fremsætter offeret sine synspunkter, og dette system er medvirkende til at knytte børnene igen til samfundet som helhed, således at de drager lærdom af denne erfaring og gør deres til at gøre samfundet mere sikkert. Man anser denne løsning for at være lykkedes godt. Det er dog ikke muligt at anvende den på tilregnelige unge, forudsat at loven er uændret. Nu er der et udvalg under justitsministeriet, hvor man skal undersøge mulighederne for at udvide anvendelsesrammen for denne praksis.

\section{Forskning}

For tre år siden udkom der en rapport om undersøgelse af forbrydelsers gentagelsesfrekvens i Island. Der undersøgte man de pågældendes karriere, som afsluttede afsoning af dom ved samfundstjeneste eller ubetinget fængselsstraf eller fik betinget dom i årene 1994-1998. Der fremgår det, at efter 3 år var $17 \%$ af dem, som afsonede ved samfundstjeneste, blevet fængslet igen, i alt $22 \%$ havde fået en ny dom, og i alt $55 \%$ var blevet anmeldt til politiet. ${ }^{17} \mathrm{De}$ tilsvarende tal for dem, som afsonede fængselsstraf, var henholdsvis $29 \%, 38 \%$ og $67 \%{ }^{18}$. Det skal dog understreges, at de, der afsoner ved samfundstjeneste, adskiller sig fra dem, som afsoner i fængsel, ved gennemgående at være ældre, have færre tidligere domme og være dømt for mindre alvorlig kriminalitet. Tilsvarende tal var $13 \%, 24 \%$ og $55 \%$ for dem som fik betinget dom. ${ }^{19}$ Sammenlignet med de to andre grupper var der større sandsynlighed for at disse dømte var kvinder, unge og var i de fleste tilfælde ikke blevet dømt tidligere.

\footnotetext{
${ }^{17}$ Baumer o. fl.: Forbrydelsers gentagelsesfrekvens i Island, s. 49.

${ }^{18}$ Baumer o. fl.: Forbrydelsers gentagelsesfrekvens i Island, s. 39-40.

${ }^{19}$ Baumer o. fl.: Forbrydelsers gentagelsesfrekvens i Island, s. 56.
} 


\section{Litteratur:}

Althingistídindi (Altingstidende):

1939, A-deild (A-del)

1987-88, A-deild (A-del)

Vefslód Althingis: http://www.althingi.is/altext/130/s/0673.html. Skoðuð 04.03.04.

Ársskýrsla Fangelsismálastofnunar ríkisins fyrir árið 1998. (Statens fængselsdirektorats årsrapport for året 1998). 1999. Reykjavík.

Ársskýrsla Fangelsismálastofnunar ríkisins fyrir árið 2001. (Statens fængselsdirektorats årsrapport for året 2001). 2002. Reykjavík.

Ársskýrsla Fangelsismálastofnunar ríkisins fyrir árið 2002. (Statens fængselsdirektorats årsrapport for året 2002). 2003. Reykjavík.

Ársskýrsla lögreglustjórans í Reykjavík fyrir árið 2001. (Politimesteren i Reykjavíks årsrapport for året 2001). 2002. Reykjavík.

Baumer, Eric, Helgi Gunnlaugsson, Kristrún Kristinsdóttir, Richard Wright. 2001. "Ítrekunartídni afbrota á Íslandi. Rannsókn á afturhvarfi brotamanna til afbrotahegðunar eftir úttekt refsingar." ("Forbrydelsers gentagelsesfrekvens i Island. En undersøgelse af recidiv blandt kriminelle efter afsonet straf"). Reykjavík.

Bragadóttir, Ragnheidur. 2000. "Samfélagsthjónusta - á réttri leid?" ("Samfundstjeneste på rigtig vej?”). I: Afmælisrit Thórs Vilhjálmssonar (Festskrift til Thór Vilhjálmsson). Side 457-486. Reykjavík: Bókaútgáfa Orators.

Bragadóttir, Ragnheidur. 2001. "Samfélagsviðurlög utan fangelsis". ("Samfundssanktioner uden for fængslerne"). I: Afmælisrit til heidurs Gunnari G. Schram. (Festskrift til Gunnar G. Schram). Side 397-413. Reykjavík: Almenna bókafélagid.

Bragadóttir, Ragnheidur: 2001. "Samfundssanktioner i Island." Nordisk Tidsskrift for Kriminalvidenskab. Nr. 2: Side 136-153.

Skýrsla nefndar um reynslulausn. (Rapport fra udvalget om prøveløsladelse). 2004. Dóms- og kirkjumálaráđuneytio. (Justits- og kirkeministeriet). Reykjavík.

Skýrsla nefndar um unga afbrotamenn. (Rapport fra udvalget om unge kriminelle). 1999. Dóms- og kirkjumálaráðuneytið. (Justits- og kirkeministeriet). Reykjavík.

Adresse:

Det juridiske fakultet

Islands Universitet

IS-101 Reykjavík

rb@hi.is 